\begin{abstract}
About authors:
Sychev Dmitry, MD, DMSc, Professor, corresponding member of Russian academy of sciences; Head of department of clinical pharmacology and therapy; e-mail: dmitry.alex.sychev@gmail.com

Bordovsky Sergey, 5-year medical student; e-mail: Arhont7@bk.ru

Nikulin Vladislav, 5-year medical student; e-mail: texet460@me.com

Polshina Natalia, 5-year medical student; e-mail: Natalya-poshina@yandex.com

Anikin Georgiy, MD, Associate professor at the department of clinical pharmacology and therapy; e-mail: medi321@mail.ru

Danilina Kristina, applicant at the department of clinical pharmacology and therapy; e-mail: kristina90.90@bk.ru

Smirnov Valeriy, CPhs, Head of the laboratory of clinical pharmacology № 73, associate professor at the department of pharmaceutical and toxicological chemistry; e-mail: pharma@bk.ru
\end{abstract}

(c) Ketova G. G., Barysheva V. O., 2017

UDC 615.015154+614.2-082.039

DOI - https://doi.org/10.14300/mnnc. 2017.12087

ISSN - 2073-8137

\title{
PHARMACOGENETIC TESTING ON WARFARIN AND CLOPIDORGEL IN CONDITIONS OF A MULTIPROFILE HOSPITAL
}

\author{
Ketova G. G., Barysheva V. O.
}

South Ural State Medical University, Chelyabinsk, Russian Federation

\section{ФАРМАКОГЕНЕТИЧЕСКОЕ ТЕСТИРОВАНИЕ НА ВАРФАРИН И КАОПИАОГРЕА В УСАОВИЯХ МНОГОПРОФИАЬНОГО СТАЦИОНАРА}

\author{
Г. Г. Кетова, В. О. Барышева
}

\section{Южно-Уральский госуАарственный меАицинский университет, Челябинск, Российская ФеАерация}

In the study 236 patients was included. Decoding of the genotypes was carried out with kits of reagent for determining genetic polymorphisms associated with the metabolism of warfarin or clopidogrel with detection PCR results in real-time; and melting curve analysis, qualitative analysis ("NPO DNA-Technology», Russia). The age mean age of the patients was $57.5 \pm 12.01$ years. Gender differences included $54.6 \%$ male. Clopidogrel sensitivity is influenced by several genetic polymorphisms: ABCB1: CC - 19.1\%, CT - 42.6\%, TT - 31.2\%. CYP2C19*2: GG - 78.7\%, AA $2.1 \%$. CYP2C19*3: GG - $100 \%$. CYP2C19*17: CC $-57.4 \%$, CT $-36.9 \%$, TT $-5.7 \%$. Allelic variants: $1 /{ }^{*} 1-39.7 \%$, ${ }^{\star} 1 /{ }^{*} 2-15.6 \%,{ }^{\star} 2 /{ }^{*} 17-4.3 \%,{ }^{\star} 2 /{ }^{\star} 2-2.1{ }^{*} 1 /{ }^{\star} 17-32.6 \%,{ }^{\star} 17 /{ }^{*} 17-5.7 \%$. Thus, the prevalence of genotypes associated with resistance to clopidogrel in the studied population is $22.0 \%$. The frequency of genotypes associated with high sensitivity to warfarin in the studied population was: CYP2C9* $1 /{ }^{\star} 2-17.9 \%, \mathrm{CYP} 2 \mathrm{C} 9{ }^{\star} 1 /{ }^{\star} 3-13.7 \%, \mathrm{CY}-$ P2C9 *2/ $23-2.1 \%$, AA VKORC $1-21.1 \%$

Keywords: pharmacogenetics, pharmacogenetic testing, warfarin, clopidogrel, personalized medicine

Исследование включило 236 пациентов. Расшифровка генотипов проводилась с помощью наборов реагентов для определения генетических полиморфизмов, ассоциированных с метаболизмом варфарина или клопидогрела, с детекцией результатов ПЦР в реальном времени; анализ кривых плавления, качественный

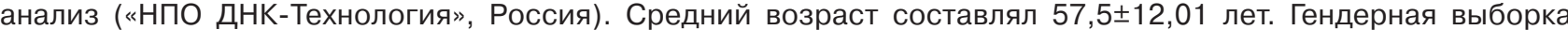
включила 54,6 \% пациентов мужского пола. На чувствительность к клопидогрелу влияли несколько генетических полиморфизмов: АВСВ1: СC - 19,1\%, СТ - 42,6 \%, TT - 31,2 \%; CYP2C19*2: GG - 78,7 \%, AA - 2,1\%; CYP2C 19*3: GG - $100 \%$; CYP2C 19*17: CC - 57,4\%, CT - 36,9\%, TT - 5,7\%. Allelic variants: $1 /{ }^{\star} 1-39,7 \%,{ }^{*} 1 /{ }^{\star} 2-$ $15,6 \%,{ }^{\star} 2 /{ }^{\star} 17-4,3 \%,{ }^{\star} 2 /{ }^{\star} 2-2,1 * 1 /{ }^{\star} 17-32,6 \%,{ }^{\star} 17 /{ }^{\star} 17-5,7 \%$. Таким образом, распространенность генотипов, ассоциированных с резистентностью к клопидогрелу в исследуемой популяции, составляет $22,0 \%$. Частота генотипов, связанных с высокой чувствительностью к варфарину, в исследуемой популяции составила: CYP2C9 *1/*2 - 17,9 \%, CYP2C9 * $1 /{ }^{\star} 3-13,7 \%$, CYP2C9 *2/ $3-2,1 \%$, AA VKORC $1-21,1 \%$.

Ключевые слова: фармакогенетика, фармакогенетическое тестирование, варфарин, клопидогрел, персонализированная медицина

P harmacogenetics and pharmacogenomics aim to establish the influence of genetic factors on drug efficacy and adverse reactions.

Genetic polymorphisms, SNPs (Single Nucleotide Polymorphism) being the most common, are minimal changes in genetic information, present in more than
$1 \%$ of the population, considered to be normal variants, but nevertheless, in certain circumstances, they may have a phenotypic impact. These genetic polymorphisms make an important contribution to the great inter-individual and inter-ethnic variability in drug response [7]. 
Warfarin is the most widely prescribed anticoagulant for thromboembolic therapy. However, owing to its narrow therapeutic index and the large inter-individual variability in its maintenance dose, warfarin is not easy to dose. To determine the effective therapeutic dose, frequent monitoring of the international normalized ratio (INR) followed by careful dose adjustments is required for each individual and it often takes 30-60 days to find out the maintenance dose.

Genetic variations in the CYP2C9 and VKORC1 genes could significantly influence warfarin responsiveness across various ethnic groups, because products of these genes play essential roles in the pharmacokinetics and pharmacodynamics of warfarin [2].

Clopidogrel is a prodrug, requiring metabolism before it can inhibit adenosine diphosphate-induced platelet aggregation. The pharmacodynamic response to clopidogrel varies widely from subject to subject, and about $25 \%$ of patients treated with standard clopidogrel doses display low ex vivo inhibition of ADP-induced platelet aggregation.

This poor response to clopidogrel is associated with an increased risk of recurrent ischemic events $[4,9]$.

There is growing evidence that the response to clopidogrel may be influenced by pharmacokinetic variables such as intestinal absorption and metabolic activation in the liver, both of which are affected by genetic polymorphisms [4, 9].

Hepatic metabolization of clopidogrel is achieved by a different hepatic CYP isoenzymes, including CYP2C19, $3 \mathrm{~A} 4 / 5,1 \mathrm{~A} 2,2 \mathrm{~B} 6$, and $2 \mathrm{C} 9$. Evidence is accumulating that the polymorphically expressed isoenzyme CYP2C19 constitutes a dominant part in this process. A loss-offunction polymorphism in the CYP2C19 gene, known as the CYP2C19*2 allelic variant, has been associated with higher levels of ADP-induced platelet aggregation values in clopidogrel-treated patients and consequently a higher risk of major adverse cardiovascular events, including the occurrence of stent thrombosis (ST) [8].

Material and Methods. This study was carried out 2013-2016 in Chelyabinsk. Pharmacogenetic testing for identifying of warfarin sensitivity, clopidogrel resistance and for selection of doses of proton pump was initiated in the Clinic of South Ural state medical University.

In the study blood of 236 patients was used as the genetic material for PCR. Obtaining a DNA sample from whole peripheral blood for genetic studies was made using the kit of reagents for DNA extraction "SAMPLERAPID-GENETICS» («NPO DNA-Technology»).

Decoding of the genotypes was carried out on the detecting amplifier DT-96 («NPO DNA-Technology», Russia) with detection of the PCR results in real time and kits of reagent for determining genetic polymorphisms associated with the metabolism of warfarin or clopidogrel with detection PCR results in real-time; and melting curve analysis, qualitative analysis («NPO DNA-Technology», Russia).

Interpreting the results of pharmacogenetic testing on clopidogrel resistance was based on practical recommendations and the information in The Pharmacogenomics Knowledgebase (www.pharmgkb. org). Determinations of warfarin dose were also based on practical recommendations and online calculator (www. warfarindosing.org).

After interpretation of results personalized selection of therapy, including the identification of a suitable drug and dosing regime was carried out. Statistics analysis was carried out using the program SPSS Statistics 15.0.

Results and Discussion. The study included the results of the 95 pharmacogenetic tests to determine warfarin sensitivity. The age of patients ranged from 14 to 82 years (mean age $63.0 \pm 11.57$ years), $34.7 \%$ of the patients were male, mean weight of patients was $86.3 \pm 22.6 \mathrm{~kg}$ (from $48 \mathrm{~kg}$ to $150 \mathrm{~kg}$ ), mean height $165.7 \pm 9.5 \mathrm{~cm}$ (from $144 \mathrm{~cm}$ to $189 \mathrm{~cm}$ ). All patients were classified as Caucasian. $13.7 \%$ of patients were smokers.

Among the indications for the testing the most common was atrial fibrillation $(70.5 \%)$. Patients also received warfarin because of a prosthetic valve $(12.6 \%)$, both prosthetic valve and atrial fibrillation (4.3\%), after thrombosis of different localization (including stroke and deep vein thrombosis) (5.3\%) and other indications (7.4\%).

Liver diseases (cirrhosis, steatosis, chronic viral hepatitis $\mathrm{C}$ ) that may change the metabolism of warfarin were detected in $5.3 \%$ of patients.

Also it is needed to consider the daily dose of several drugs:

Amiodarone: most of patients $(90.5 \%)$ did not receive amiodarone, $3.2 \%$ of patients received this drug in a dose of $600 \mathrm{mg} /$ day, $2.1 \%$ in the dose of $200 \mathrm{mg} /$ day and $1.1 \%$ of patients were treated with amiodarone at doses of $50,300,400$ and $1200 \mathrm{mg} /$ day.

Statins: $33.7 \%$ of patients did not use statins. The rest used atorvastatin (31.6\%), rosuvastatin (15.8\%) or simvastatin (18.9\%).

Antifungal drugs and sulfonamides: $100 \%$ of patients did not accept these drugs.

The warfarin sensitivity is influenced by several genetic polymorphisms:

VKORC 1 is a gene on 16 chromosome, which encodes vitamin $\mathrm{K}$ epoxide reductase complex subunit 1 and is responsible for the recovery of vitamin K. Several SNPs are associated with warfarin dose, which is different from normal.

Among our patients most often were heterozygotes GA (43.2 \%), homozygotes AA and GG were found less frequently (21.1\% and $35.8 \%$ of cases respectively) .

CYP2C9 is the main enzyme responsible for the inactivation of warfarin [5]. The two most common mutations in the gene CYP2C9 $\left({ }^{*} 2\right.$ and $\left.{ }^{*} 3\right)$ require the appointment of lower doses of warfarin because the gene loses its functionality, and warfarin remains in the blood longer. Polymorphisms of CYP2C9 significantly dependent on race.

In our study the most common variant of CYP2C9*2 was homozygous variant CC $(80.0 \%)$ and the most rare was homozygous variant TT $(1.1 \%)$. The heterozygous variant was found in $18.9 \%$ of patients.

It was shown that the allelic variant CYP2C9*3 also influences the variation of warfarin dose $[1,7]$. Among the treated patients AA was found in $83.2 \%$ cases, AC in $16.8 \%$. Homozygous CC was not found.

Several studies have also found a link SNP CYP4F2 $1347 \mathrm{G}>\mathrm{A}$ (rs2108622) and maintenance doses of oral anticoagulants [2]. Among the patients in our study frequency of the homozygous variant CC amounted to $61.0 \%$, the homozygous variant TT was detected in $7.4 \%$, the heterozygous variant CT in $31.6 \%$.

Thus in our study the allelic variant ${ }^{*} 1 /{ }^{*} 1$ was met in $66.3 \%$ patients, ${ }^{*} 1 /{ }^{\star} 2$ in $17.0 \%,{ }^{*} 1 /{ }^{\star} 3$ in $13.0 \%$ and ${ }^{\star} 2 /{ }^{\star} 3$ was detected in $2.2 \%$ of cases. The dose of warfarin was selected individually. The minimum dose selected by using pharmacogenetic testing was $0,7 \mathrm{mg}$, the maximum dose was $9.8 \mathrm{mg}$. The average dose was $4.0 \pm 1.77 \mathrm{mg}$. Frequency of genotypes associated with high sensitivity to warfarin in the study population was: CYP2C9*1/*2 - $17.9 \%$, CYP2C9* $1 /{ }^{\star} 3-13.7 \%$, CYP2C9 ${ }^{\star} 2 /{ }^{*} 3-2.1 \%$ G3673A (AA) of VKORC $1-21.1 \%$.

141 tests were analyzed to assess the frequency of distribution of genotypes associated with resistance to 
clopidogrel. Due to the fact that for the selection of doses of proton pump inhibitors are used the same points a combined test to determine these two parameters is used in the Clinic of the South Ural state medical University.

The age of the patients ranged from 23 to 83 years (mean age was $57.5 \pm 12.01$ years). Gender differences included 77 male $(54.6 \%)$ and 64 female patients (45.4\%).

This patients had different indications for receiving clopidogrel: myocardial infarction $(7.1 \%)$, coronary artery stenting $(17.0 \%)$, other forms of CHD (26.2\%), stroke $(2.1 \%)$. For $47.5 \%$ of patients this analysis was conducted to study the frequency of genotypes associated with resistance to clopidogrel, with no indications for taking this drug at the time of blood sampling.

For the formation of the conclusion about resistance to clopidogrel genetic information is also needed:

1. ABCB1 (MDR1) - this gene encodes P-glycoprotein and is responsible for intestinal absorption of clopidogrel. Variants of this gene have an impact on clopidogrel therapy $[6,11]$, reducing its effectiveness in some cases.

Among our patients genotype CC was detected in $19.1 \%$ of patients, CT in $42.6 \%$ and TT in $31.2 \%$ of patients.

\section{CYP2C19}

Resistance to clopidogrel in patients with cardiovascular diseases in different populations is associated with genetic variants of cytochrome P450(CYP) [5, 10]. Polymorphisms of CYP2C19 affect both phases of liver metabolism of clopidogrel. Carriers of at least one of CYP2C19 alleles associated with slow metabolism ( ${ }^{\star} 2$ or ${ }^{\star} 3$ ) have lower plasma concentrations of the active metabolite and lower inhibition of platelet aggregation [8].

The analysis of patients results for determination of the alleles CYP2C19*2 in our study revealed that «wild» type GG was most common $(78.7 \%)$, and variant $A A$ was the most rare $(2.1 \%)$. Heterozygotes were found in $19.1 \%$ of cases.

3. Allele CYP2C $19{ }^{\star} 3$ is also associated with resistance to clopidogrel. Wild type is the genotype $\mathrm{GG}$ is associated with normal activity of clopidogrel. All patients in our study were carriers of GG genotype.

4. Allele CYP2C $19 * 17(-806 \mathrm{C}>\mathrm{T})$ is associated with the phenotype of ultrafast metabolism [11] and reduced efficacy of standard doses of proton pump inhibitors [3, 12]. Carriers of this polymorphism also associated with an increased risk of bleeding on clopidogrel [8].

According to our study most often were variants CC $(57.4 \%)$ and CT $(36.9 \%)$. The TT variant was found in $5.7 \%$ of cases.

\section{References}

1. Buzoianu A., Trifa A., Mureșanu D., Crișan S. Analysis ofCYP2C9*2,CYP2C9*3andVKORC1-1639 G>A polymorphisms in a population from South-Eastern Europe. Journal of Cellular and Molecular Medicine. 2012;16(12):2919-2924. doi: 10.1111/j.15824934.2012.01606.x

2. Cha P., Mushiroda T., Takahashi A., Kubo M., Minami S. [et al.] Genome-wide association study identifies genetic determinants of warfarin responsiveness for Japanese. Human Molecular Genetics. 2010;19(23):4735-4744. doi: $10.1093 / \mathrm{hmg} / \mathrm{ddq} 389$

3. Furuta T., Sugimoto M., Shirai N. Individualized Therapy for Gastroesophageal Reflux Disease. Molecular Diagnosis \& Therapy. 2012;16(4):223-234. doi: $10.2165 / 11634960-000000000-00000$

4. Hulot J. Cytochrome P450 2C19 loss-offunction polymorphism is a major determinant of clopidogrel responsiveness in healthy subjects.
The carriers of the allelic variant ${ }^{*} 1 /{ }^{*} 1$ are «extensive metabolizers" (EM), for them clopidogrel is used at doses in accordance with the instructions. Patients with genotype ${ }^{*} 1 /{ }^{*} 2,{ }^{*} 1 /{ }^{*} 3,{ }^{*} 2 /{ }^{*} 17$ are intermediate metabolizers» (IM) and are characterized by a less decrease in platelet aggregation than normal and a higher residual platelet aggregation, and increased risk of cardiovascular events. "Poor metabolizers» (PM) $\left({ }^{\star} 2 /{ }^{\star} 2,{ }^{\star} 2 /{ }^{*} 3\right.$ and $\left.{ }^{\star} 3 /{ }^{\star} 3\right)$ are characterized by decreasing of platelet aggregation significantly below normal, increasing of residual platelet aggregation and the risk of adverse cardiovascular events.

For the group of «ultrafast metabolizers» (UM), which are the carriers of variants $* 1 /{ }^{*} 17$ and $* 17 /{ }^{*} 17$, and characterized by increasing of antiplatelet activity and reduction in residual platelet aggregation, which may be associated with the risk of bleeding. However, treatment with clopidogrel should be undertaken in accordance with the instruction.

Among our patients allelic variant ${ }^{*} 1 /{ }^{*} 1$ (extensive metabolizers) was identified in $39.7 \%$ of patients. From the intermediate metabolizers were detected variants ${ }^{*} 1 /{ }^{*} 2(15.6 \%)$ and ${ }^{*} 2 /{ }^{*} 17$ (4.3\%), among poor metabolizers was identified variant $* 2 /{ }^{*} 2(2.1 \%)$ and from ultrafast metabolizers were identified variants * $1 /{ }^{*} 17(32.6 \%)$ and * $17 /{ }^{*} 17(5.7 \%)$.

Thus, among all patients in our study, mutations were not detected in $39.7 \%$ of patients, $22.0 \%$ of patients were resistant to clopidogrel and $38.3 \%$ of patients were characterized by rapid biotransformation of proton pump inhibitors.

According to the recommendations of the European cardiology society, in the case of the detection of resistance to clopidogrel it is required to replace this drug on ticagrelor or prasugrel or to use a double dose of clopidogrel.

Among all patients antiplatelet therapy is the standard of clopidogrel is suitable for 110 patients $(78.0 \%)$, and 31 patients $(22.0 \%)$ required replacement of clopidogrel to another drug because of resistance.

Conclusions. The results of pharmacogenetic testing showed that the prevalence of genotypes associated with resistance to clopidogrel in the studied population is $22.0 \%$ (frequency of allelic variants: ${ }^{*} 1 /{ }^{\star} 2-15.6 \%$, ${ }^{\star} 2 /{ }^{*} 17-4.3 \%,{ }^{\star} 2 /{ }^{\star} 2-2.1 \%$ ), that could lead to a reduction or complete absence of effect of medical therapy with clopidogrel in every fifth patient receiving this drug.

The frequency of genotypes associated with high sensitivity to warfarin in the studied population was: CYP2C9 ${ }^{*} 1 /{ }^{\star} 2-17.9 \%$, CYP2C9 ${ }^{*} 1 /{ }^{\star} 3-13.7 \%$, CYP2C9 ${ }^{*} 2 /{ }^{*} 3-2.1 \%$, G3673A(AA) VKORC $1-21.1 \%$.

Blood. 2006;108(7):2244-2247. doi: 10.1182/ blood-2006-04-013052

5. Johnson M., Richard C., Bogdan R., Kidd R. Warfarin Dosing in a Patient withCYP2C9*3*3andVKORC1-1639 AAGenotypes. Case Reports in Genetics 2014:1-4 doi: $10.1155 / 2014 / 413743$

6. Karaźniewicz-Łada M., Danielak D., Rubiś B., Burchardt P., Komosa, A. [et al.] Impact of common $A B C B 1$ polymorphism on pharmacokinetics and pharmacodynamics of clopidogrel and its metabolites. Journal of Clinical Pharmacy and Therapeutics. 2014;40(2):226-231. doi: 10.1111/jcpt.12236

7. Militaru F. C., Vesa S. C., Pop T. R. [et al.] Pharmacogenetics aspects of oral anticoagulants therapy. J. Med. Life. 2015;8 (2):171-175.

8. Sibbing D., Koch W., Gebhard D., Schuster T., Braun S. [et al.] A. Cytochrome 2C19*17 Allelic Variant, Platelet Aggregation, Bleeding Events, and Stent Thrombosis in Clopidogrel-Treated Patients With Coronary 
Stent Placement. Circulation. 2010;121(4):512-518. doi: 10.1161/CIRCULATIONAHA. 109.885194

9. Simon T., Verstuyft C., Mary-Krause M., Quteineh L., Drouet E. [et al.] Genetic determinants of response to clopidogrel and cardiovascular events. N. Engl. J. Med. 2009;360:363-375. doi: 10.1056/NEJMoa0808227

10. Sychev D., Denisenko N., Sizova Z., Grachev A., Velikolug K. The frequency of CYP2C19 genetic polymorphisms in Russian patients with peptic ulcers treated with proton pump inhibitors. Pharmacogenomics and Personalized Medicine. 2015. doi: 10.2147/PGPM.S78986
11. Taubert D., Vvonbeckerath N., Grimberg G., Lazar A., Jung N. [et al.] Impact of P-glycoprotein on clopidogrel absorption. Clinical Pharmacology \& Therapeutics. 2006;80(5):486-501. doi: 10.1016/j.clpt.2006.07.007

12. Yang J., Lin C. CYP2C19 genotypes in the pharmacokinetics/pharmacodynamics of proton pump inhibitor-based therapy ofHelicobacter pyloriinfection. Expert Opinion on Drug Metabolism \& Toxicology. 2009;6(1):29-41. doi: 10.1517/17425250903386251

\title{
About authors:
}

Ketova Galina Grigorievna, MD, PhD, Professsor, Head of the division of scientific-educational center «Clinical pharmacology»; tel.: +73517287221; e-mail: galina_ketova@mail.ru

Barysheva Valeriya Olegovna, MD, junior researcher of scientific-educational center «Clinical pharmacology»; tel.: +79028910471; e-mail: Valeriya.bar@mail.ru

(C) Group of authors, 2017

UDC 616.72-002.77:576.524

DOI - https://doi.org/10.14300/mnnc.2017.12092

ISSN - 2073-8137

\section{SOLUBLE MOLECULES OF IMMUNOGLOBULINS SUPERFAMILY IN RHEUMATOID ARTHRITIS}

Koroy P. V., Sarithala V. J., Yagoda A. V.

Stavropol State Medical University, Russian Federation

\section{РАСТВОРИМЫЕ МОАЕКУАЫ СУПЕРСЕМЕЙСТВА ИММУНОГАОБУАИНОВ ПРИ РЕВМАТОИАНОМ АРТРИТЕ}

\author{
П. В. Корой, В. А. Саритхала, А. В. Ягола \\ Ставропольский госуАарственный меАицинский университет, Российская ФеАерация
}

Relationship of intercellular adhesion molecule-1 (ICAM-1), vascular cell adhesion molecule-1 (VCAM-1) and platelet-endothelial cell adhesion molecule-1 (PECAM-1) blood levels with features of course of rheumatoid arthritis was studied. 134 patients with rheumatoid arthritis (104 women, 30 men) at age from 20 to 66 years included in study. Duration of joint syndrome was $11.06 \pm 0.72$ years. In majority of patients high degree of activity, III radiological stage, II and III functional classes of rheumatoid arthritis were diagnosed. Plasma concentration of adhesion molecules was studied by means of ELISA.

Increase of levels of all adhesion molecules was observed $(p<0.05)$. concentration of VCAM-1 and PECAM-1 in plasma was higher in seropositive patients or in presence of antibodies to cyclic citrullinated protein $(p<0.05)$. In patients with late clinical stage levels of ICAM-1 and PECAM-1 were higher, than in early rheumatoid arthritis $(p<0.05)$. High activity of disease was combined with raised plasma levels of ICAM-1 $(p<0.05)$. Presense of systemic manifestations of disease and hematological disorders (hyperthrombocytosis) was accompanied by higher blood levels of all adhesion molecules $(p<0.05)$. In values of SCORE scale of 5 and more points concentration of ICAM- 1 and VCAM- 1 in blood was higher $(p<0.05)$, than in cases of low and moderated cardiovascular risk.

Thus, the pathogenetic importance of immunoglobulins superfamily molecules in formation and progressing of rheumatoid arthritis is proved. Strengthening of adhesive function of endothelium is interfaced to increased cardiovascular risk

Keywords: rheumatoid arthritis, immunoglobulins superfamily molecules, activity, systemic manifestations, cardiovascular risk

Изучена взаимосвязь плазменного содержания молекул межклеточной адгезии-1 (ICAM-1), адгезии сосудистого эндотелия-1 (VCAM-1), адгезии эндотелия и тромбоцитов-1 (PECAM-1) с особенностями течения ревматоидного артрита. Обследовано 134 больных ревматоидным артритом (104 женщины, 30 мужчин) в возрасте от 20 до 66 лет. Длительность суставного синдрома составила 11,06 0,72 лет. У большинства пациентов диагностированы высокая степень активности, III рентгенологическая стадия, II и III функциональные классы ревматоидного артрита. Концентрация изучаемых молекул в плазме определялась методом ИФА.

Установлено увеличение содержания всех молекул адгезии $(\mathrm{p}<0,05)$. Концентрация VCAM-1 и PECAM-1 в плазме была выше у серопозитивных пациентов или при наличии антител к циклическому цитруллинированному пептиду $(p<0,05)$. У больных с поздней клинической стадией значения ICAM-1 и РЕСАМ-1 были выше, 